\title{
The Integration of Catalytic Processes \\ of Acid Hydrolysis and Peroxide Delignification to Obtain the Bioethanol from Aspen Wood
}

\author{
Boris N. Kuznetsov*, Olga V. Yatsenkova, \\ Andrei M. Skripnikov, Natalia G. Beregovtsova, \\ Svetlana A. Kozlova and Natalia M. Ivanchenko \\ Institute of Chemistry and Chemical Technology SB RAS \\ FRC "Krasnoyarsk Science Center SB RAS" \\ 50/24 Akademgorodok, Krasnoyarsk, 660036, Russia
}

Received 19.03.2017, received in revised form 16.06.2017, accepted 09.07.2017

\begin{abstract}
The processes of catalytic hydrolysis of hemicelluloses and cellulose of aspen wood were studied at the temperatures 100 and $150{ }^{\circ} \mathrm{C}$. The dissolved mineral acids $\left(\mathrm{H}_{2} \mathrm{SO}_{4}, \mathrm{HCl}\right)$, ion exchange resin Amberlyst-15 and acid-modified SBA-15, Sibunit-4 were used in hydrolysis of aspen wood as the catalysts. The optimal conditions for the implementation of catalytic processes of acid hydrolysis of wood hemicelluloses, peroxide delignification of lignocellulose and hydrolysis of cellulose for the production of hydrolysates with the maximum glucose yield and the minimum amount of inhibitors of enzymatic processes (furfural and 5-hydroxymethylfurfural) were established. The estimated yields of bioethanol obtained by integration of optimized catalytic processes of acid hydrolysis of polysaccharides and peroxide delignification of lignocellulose of aspen wood were evaluated.
\end{abstract}

Keywords: aspen wood, catalysts, $\mathrm{H}_{2} \mathrm{SO}_{4}, \mathrm{HCl}$, solid acid, hydrolysis, peroxide delignification, hemicelluloses, cellulose, lignocellulose, xylose, glucose, 5-hydroxymethylfurfural, furfural, ethanol.

(C) Siberian Federal University. All rights reserved

* Corresponding author E-mail address: inm@icct.ru 


\title{
Интеграция каталитических процессов
}

\section{кислотного гидролиза и пероксидной делигнификации для получения биоэтанола из древесины осины}

\author{
Б.Н. Кузнецов, О.В. Яценкова, А.М. Скрипников, \\ Н.Г. Береговцова, С.А. Козлова, Н.М. Иванченко \\ Институт химии и химической технологии СО РАН \\ ФИЦ «Красноярский научный иентр СО РАН» \\ Россия, 660036, Красноярск, Академгородок, 50/24
}

Изучень процессы каталитического гидролиза гемицеллюлоз и цчеллюлозы древесины осины при температурах 100 и $150{ }^{\circ} \mathrm{C}$. В качестве катализаторов гидролиза использовали растворенные минеральные кислоты $\left(\mathrm{H}_{2} \mathrm{SO}_{4}, \mathrm{HCl}\right)$, ионообменную смолу Amberlyst-15 u кислотно-модифицированные SBA-15, Сибунит-4. Определены оптимальные условия осуществления каталитических процессов кислотного гидролиза гемицеллюлоз древесинь, пероксидной делигнификации лигноцеллюлозы и гидролиза целлюлозы для получения гидролизатов с максимальным содержанием глюкозы и минимальным количеством ингибиторов ферментативных прочессов - фурфурола и 5-гидроксиметилфурфурола. Рассчитан предполагаемый выход биоэтанола, получаемого при интеграции оптимизированных каталитических прочессов кислотного гидролиза полисахаридов и пероксидной делигнификации лигночеллюлозы древесины осины.

Ключевые слова: древесина осины, катализаторы, $\mathrm{H}_{2} \mathrm{SO}_{4}, \mathrm{HCl}$, твердые кислотные, гидролиз, пероксидная делигнификация, гемицеллюлозы, целлюлоза, лигноцеллюлоза, ксилоза, глюкоза, 5-гидроксиметилфурфурол, фурфурол, этанол.

\section{Введение}

Биоэтанол является перспективным заменителем традиционных видов углеводородного топлива [1-4]. Его уже используют в странах Латинской Америки и США в качестве транспортного топлива и как добавку в углеводородные топлива.

Для производства этанола в большинстве стран преимущественно используется пищевое сырье (зерно, кукуруза, маис, сахарный тростник), что усугубляет проблему дефицита продовольствия в мире. По объемам производства биотоплива в мире лидируют три страны: США (42 \% мирового производства), Бразилия (29 \%) и Европейский союз (18 \%).

Получение этанола из целлюлозной части биомассы, например деревьев, травы, сельскохозяйственный отходов, является перспективным процессом, позволяющим использовать дешевое непродовольственное сырье. Считается, что Соединенные Штаты могли бы удовлетворить около половины спроса на топливо, используя целлюлозное сырье, не затрагивая продовольствие $[5,6]$.

В настоящее время формируется крупномасштабное производство биоэтанола из лигноцеллюлозной биомассы [7]. При этом основной проблемой, требующей технологического ре- 
шения, является разработка эффективного метода получения глюкозных гидролизатов из целлюлозы.

В России сосредоточены огромные ресурсы древесной биомассы. Низкосортная древесина (осина, береза) и древесные отходы практически неисчерпаемое возобновляемое сырье для производства биоэтанола. Среди лиственных пород деревьев второе место по площади произрастания занимает осина. В древесине осины присутствуют в значительном количестве гемицеллюлозы [8], затрудняющие применение традиционных технологий ее переработки в глюкозные гидролизаты для синтеза биоспиртов. Глюкозные гидролизаты, полученные непосредственно из древесины, загрязнены примесями (фурановыми соединениями, терпенами, фенолами и танинами), ингибирующими ферментативные процессы и снижающими выход этанола [9]. В связи с этим целесообразно предварительно осуществлять щелочное [10] или кислотное [11] фракционирование древесины с выделением ксилозы [12], фурфурола [13], лигнина [14] в качестве дополнительных ценных продуктов.

В настоящее время развиваются исследования процессов гидролиза гемицеллюлоз и целлюлозы в присутствии не только растворенных [15], но и твердых кислотных катализаторов [16]. Преимущества использования твердых кислотных катализаторов заключаются в экологической безопасности, отсутствии коррозионной активности и дополнительных затрат на нейтрализацию реакционных растворов [17].

Для получения качественных глюкозных гидролизатов для ферментативного синтеза биотанола из лигноцеллюлозного сырья предлагается использовать процессы окислительного фракционирования биомассы на целлюлозу и растворимые продукты из лигнина и гемицеллюлоз [18-20].

Целью настоящего исследования являлась разработка методов получения качественных глюкозных гидролизатов из древесины осины, основанных на интеграции каталитических процессов кислотного гидролиза полисахаридов и пероксидной делигнификации древесины.

\section{Экспериментальная часть}

\section{Исходные материалы и реактивы, катализаторы}

В качестве исходного сырья использовали измельченную (фракция 2-5 мм) древесину осины обыкновенной (Populus tremula), заготовленную в окрестностях г. Красноярска. Содержание гемицеллюлоз и целлюлозы в древесине осины и твердом остатке гидролизованной древесины определяли по [21], для чего проводили разделение легкогидролизуемых (ЛГПС) и трудногидролизуемых (ТГПС) полисахаридов, используя различные условия гидролиза древесины. Определение лигнина проводили по методу Класона с использованием 72 \% $\mathrm{H}_{2} \mathrm{SO}_{4}[22,23]$. Перед проведением анализов выполняли обессмоливание древесных опилок в соответствии со стандартным методом ANSI/ASTM D 1105. Для определения зольности высушенные опилки прокаливали в фарфоровом тигле в муфельной печи при температуре $575 \pm 25{ }^{\circ} \mathrm{C}$ в течение $3-4$ ч до полного удаления углерода (отсутствие черных точек), затем остужали и охлаждали в эксикаторе, взвешивали и продолжали прокаливать по 1 ч до достижения постоянной массы [24].

Химический состав древесины осины (\% от массы абс. сух. древесины): целлюлоза 47,3; лигнин 22,9; гемицеллюлозы 24,5; зола 0,5.

$$
-335-
$$


В качестве растворенных катализаторов гидролиза древесины осины использовали серную кислоту «хч» ГОСТ 4204-77 или соляную кислоту «хч» ГОСТ 3118-77. Все растворы готовили с применением дистиллированной воды ГОСТ 6709-72.

В качестве твердых кислотных катализаторов гидролиза древесины осины использовали кислотномодифицированные SBA-15 и Сибунит-4. Модифицирование углеродного мезопористого материала Сибунит-4 проводили, обрабатывая его сначала водным раствором азотной кислоты (35 \% об. $\mathrm{HNO}_{3}$ ), а затем дополнительно дымящейся серной кислотой по методике, изложенной в [25]. Метод двустадийного синтеза мезопористого SBA-15 включал модифицирование поверхности SBA-15 функциональными группами (прививка 3-меркаптопропилтриметоксисилана) и окисление функциональных групп до $-\mathrm{SO}_{3} \mathrm{H}$ с использованием 30 \%-ного пероксида водорода.

Текстурные свойства модифицированных материалов были исследованы методом низкотемпературной адсорбции $\mathrm{N}_{2}$ на установке ASAP-2420 (Micrometritics, CША) при T=98 К в интервале относительных давлений $\left(\mathrm{Pp} / \mathrm{pP}^{0}\right)$ 0,06-0,99 с шагом 0,015. Удельную площадь поверхности рассчитывали по модели ВЕТ в интервале $\mathrm{pP} / \mathrm{pP}^{0} 0,06-0,25$, внутренний объем пор - по методу «Singlepoint BET», а распределение пор по размерам получали по уравнению изотермы ВJН.

Концентрацию кислотных групп на поверхности катализаторов определили кислотноосновным титрованием гидроксидом натрия.

В результате прививки функциональных групп для всех образцов катализаторов наблюдается закономерное уменьшение площадей удельной поверхности и размеров пор по сравнению с исходными Сибунитом-4 и SBA-15 (табл. 1).

\section{Гидролиз и делигнификачия древесины осины}

Воздушно-сухую древесину осины предварительно подвергали механической обработке в планетарной мельнице АГО-2 в течение 30 мин при центробежном ускорении, развиваемом мелящими телами, 60 g. Планетарная мельница оснащена двумя барабанами, вращающимися вокруг центральной оси и одновременно вокруг собственных осей в противоположном направлении. В барабаны загружали древесные опилки (фракция 2-5 мм) и мелющие тела (стальные шарики диаметром 3-8 мм).

При гидролизе древесины в присутствии растворенных катализаторов $2 \%$ мас. $\mathrm{H}_{2} \mathrm{SO}_{4}$ и $2 \%$ мас. $\mathrm{HCl}$ навеску воздушно-сухих опилок древесины осины в количестве 10 г поме-

Таблица 1. Текстурные характеристики катализаторов

Table 1. Texture characteristics of modified the catalysts

\begin{tabular}{|c|c|c|c|c|}
\hline $\begin{array}{c}\text { Исходный } \\
\text { и модифицированный материал }\end{array}$ & $\mathrm{S}_{\mathrm{BET}}, \mathrm{M}^{2} / \Gamma$ & $\mathrm{V}_{\text {пор }}, \mathrm{cm}^{3} / \Gamma$ & $<\mathrm{d}>_{\text {пор }}, \mathrm{HM}$ & $\mathrm{C}_{\text {кисл. групп }}$, ммоль $\cdot^{-1}$ \\
\hline Исходный Сибунит-4 & 379 & 0,63 & 6,6 & 0,039 \\
\hline $\begin{array}{l}\text { Кислотно-модифицированный } \\
\text { Сибунит-4 }\end{array}$ & 267 & 0,36 & 5,3 & 0,482 \\
\hline Исходный SBA-15 & 550 & 0,82 & 5,9 & - \\
\hline Кислотно-модифицированный SBA-15 & 417 & 0,59 & 5,6 & 0,705 \\
\hline
\end{tabular}


щали в стеклянный реактор из термостойкого стекла объемом 350 мл, снабженный мешалкой и обратным холодильником, реактор устанавливали в термостат. Затем к древесным опилкам приливали 80 мл 2\%-ного раствора $\mathrm{H}_{2} \mathrm{SO}_{4}$ или 2\%-ного раствора $\mathrm{HCl}$. Гидролиз проводили при атмосферном давлении, температуре $100{ }^{\circ} \mathrm{C}$, в течение 60-300 мин, при интенсивности перемешивания 14 об/с. По истечении заданного времени полученный гидролизат остужали в ледяной ванне, отфильтровывали на воронке Бюхнера на бумажном фильтре под вакуумом, переливали в бюкс, закрывали притертой крышкой и анализировали на газовом хроматографе «VARIAN-450». Негидролизованный древесный остаток промывали дистиллированной водой до нейтральной реакции промывных вод и высушивали в сушильном шкафу при температуре $103{ }^{\circ} \mathrm{C}$. Конверсию древесины определяли весовым методом с точностью $\pm 2-3 \%$.

Гидролиз древесины осины в присутствии твердых кислотных катализаторов проводили при температуре $150{ }^{\circ} \mathrm{C}$ во вращающемся стальном автоклаве с внутренней фторопластовой пробиркой объемом 35 мл, помещенном в металлический воздушный термостат. Скорость вращения автоклава составляла 11 об/мин. Смесь древесины осины $(0,2$ г) и твердого катализатора $(0,2$ г) помещали в пробирку и заливали 5 мл дистиллированной воды. Продолжительность гидролиза варьировалась от 1 до 4 ч. По истечении заданного времени реактор охлаждали и полученный гидролизат отделяли от гидролизованной древесины и твердого катализатора на воронке Бюхнера на бумажном фильтре под вакуумом. Катализатор и негидролизованный древесный остаток промывали водой и высушивали в сушильном шкафу при температуре $103{ }^{\circ} \mathrm{C}$, а гидролизат переливали в бюкс и анализировали на газовом хроматографе.

Выделение целлюлозы из твердого остатка, образующегося при гидролизе древесины осины, осуществляли методом пероксидной делигнификации в среде уксусная кислота-вода в присутствии катализатора $2 \%$ мас. $\mathrm{H}_{2} \mathrm{SO}_{4}$ при температуре $100{ }^{\circ} \mathrm{C}$ по методике [26].

Кислотный гидролиз целлюлозы из древесины осины осуществляли в оптимальных условиях в соответствии с методикой [27].

Анализ гидролизатов древесины и целлюлозы на индивидуальный состав и содержание моносахаров проводили хроматографическим методом с использованием газового хроматографа «VARIAN-450», а определение количественного содержания микропримесей фурфурола и 5-ГМФ - методом ВЭЖХ с использованием жидкостного микроколоночного хроматографа «Милихром А-02» в соответствии с методиками [27, 28].

\section{Результаты и обсуждение}

\section{Гидролиз гемицеллюлоз древесины осинь}

Одним из путей повышения качества глюкозных гидролизатов для ферментативного синтеза этанола является предварительное удаление из древесины гемицеллюлоз и лигнина с последующим гидролизом выделенной целлюлозы [29]. Такая предварительная обработка древесины повышает содержание глюкозы в гидролизатах и минимизирует образование нежелательных примесей (фурановых соединений, терпенов, фенолов и пр.), снижающих выход биоэтанола [30].

В настоящей работе изучено влияние растворенных кислотных катализаторов $2 \%$ мас. $\mathrm{H}_{2} \mathrm{SO}_{4}$ и $2 \%$ мас. $\mathrm{HCl}$ на гидролиз гемицеллюлоз древесины осины при температуре $100{ }^{\circ} \mathrm{C}$.

$$
-337-
$$


Обнаружено, что при аналогичных условиях гидролиза степень конверсии древесины осины и выход моносахаров выше при использовании катализатора $\mathrm{HCl}$ (рис. $1 A, Б$ ).

Максимальный выход моносахаров (75 \% мас.) из гемицеллюлоз древесины осины в присутствии $2 \%$ мас. $\mathrm{HCl}$ соответствует продолжительности гидролиза 4 ч (рис. $1 Б$ ). Содержание ксилозы в этом гидролизате составляет 62,4 \% мас. от исходного содержания гемицеллюлоз в древесине осине. Помимо ксилозы, в составе гидролизатов присутствуют арабиноза, галактоза, манноза и глюкоза.

С увеличением продолжительности гидролиза усиливается вклад вторичных превращений моносахаров с образованием фурфурола и 5-гидроксиметилфурфурола (5-ГМФ), которые ингибируют процесс ферментативного синтеза биоэтанола из глюкозы. Наибольшее содержание фурфурола (0,35-0,67 г/л) и 5-ГМФ (0,04-0,07 г/л) обнаружено в гидролизатах, полученных гидролизом древесины осины в присутствии $2 \% \mathrm{Mac.} \mathrm{HCl}$ при продолжительности процесса 3-5 ч (рис. 2Б).

При температуре $150{ }^{\circ} \mathrm{C}$ каталитическая активность твердых кислотных катализаторов Amberlyst 15, кислотно-модифицированных Сибунита-4 и SBA-15 в гидролизе гемицеллюлоз древесины осины была сопоставима (рис. 3). Выбор этой температуры осуществлен в соответствии с литературными данными [25].

Максимальный выход моносахаров из гемицеллюлоз осины (73,1 \% мас.) при температуре гидролиза $150{ }^{\circ} \mathrm{C}$ наблюдается в присутствии Amberlyst 15 (рис. 3). Однако этот катализатор способствует образованию существенных количеств фурфурола (до 2 \% от массы исходной древесины осины).

\section{Пероксидная делигнификация древесины осины}

Из твердых лигноцеллюлозных продуктов гидролиза древесины осины предложено получать целлюлозу путем пероксидной делигнификации в среде «уксусная кислота-вода-
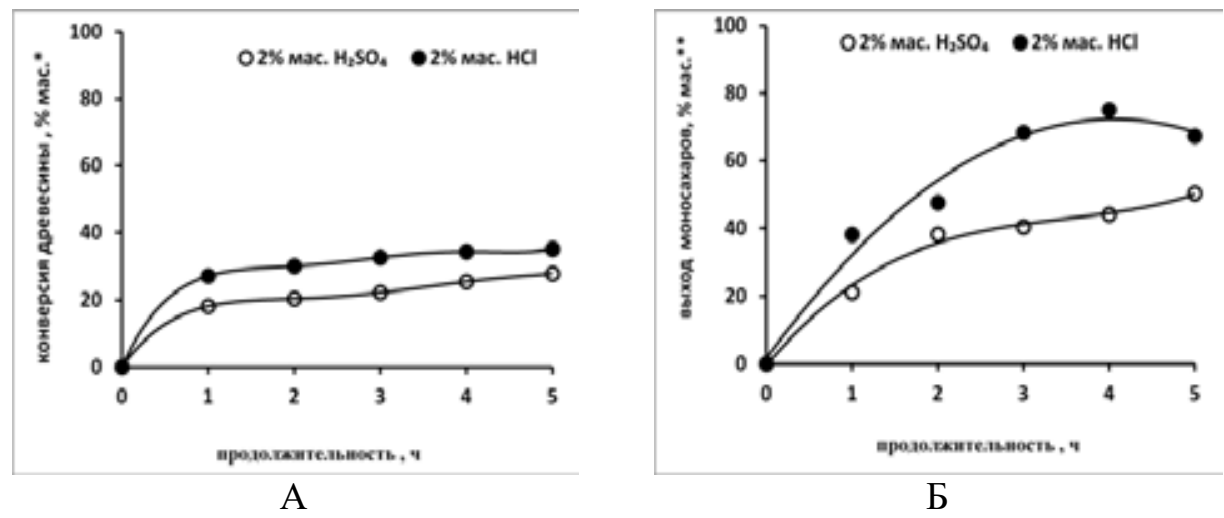

Рис. 1. Влияние продолжительности гидролиза древесины осины при температуре $100{ }^{\circ} \mathrm{C}$ на ее конверсию (А) и выход моносахаров (Б) из гемицеллюлоз в присутствии катализаторов $2 \%$ мас. $\mathrm{H}_{2} \mathrm{SO}_{4}$ и $2 \% \mathrm{Mac} . \mathrm{HCl}$ (*от массы абс. сух. древесины, ** от исходного содержания гемицеллюлоз в древесине)

Fig. 1. Effect of the reaction time of aspen wood hydrolysis at $100{ }^{\circ} \mathrm{C}$ on its conversion (A) and on the yield of monosaccharides (B) from hemicelluloses in the presence of catalysts of $2 \% \mathrm{wt} . \mathrm{H}_{2} \mathrm{SO}_{4}$ and $2 \% \mathrm{wt}$. $\mathrm{HCl}(*$ from the mass of abs. dry wood, ** from the initial content of hemicelluloses in wood) 


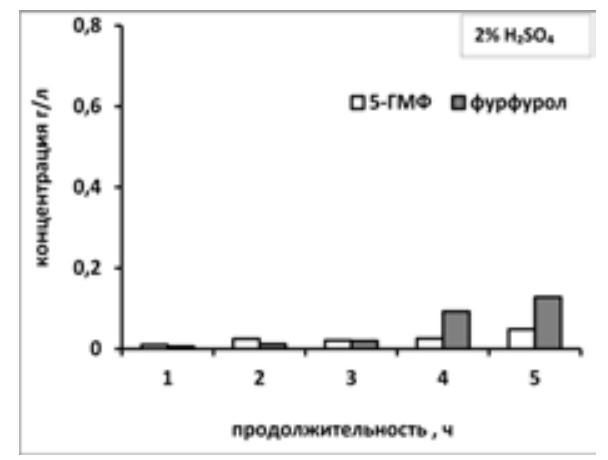

A

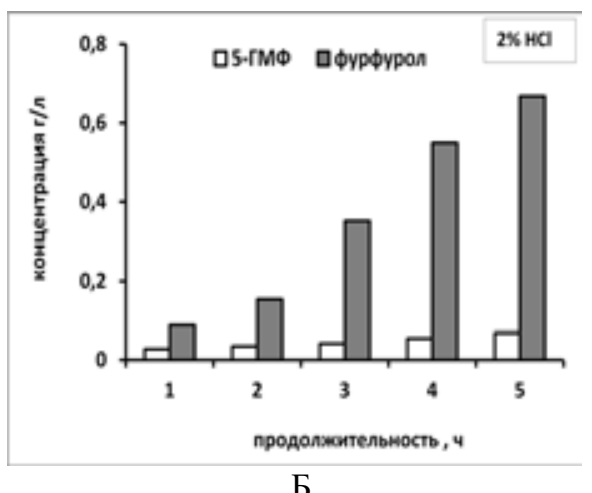

Б

Рис. 2. Влияние продолжительности гидролиза древесины осины при температуре $100{ }^{\circ} \mathrm{C}$ в присутствии $2 \%$ мас. $\mathrm{H}_{2} \mathrm{SO}_{4}(\mathrm{~A})$ и $2 \%$ мас. $\mathrm{HCl}$ (Б) на содержание 5-ГМФ и фурфурола в гидролизатах

Fig. 2. Effect of reaction time of aspen wood hydrolysis at $100{ }^{\circ} \mathrm{C}$ in the presence of $2 \% \mathrm{wt} \mathrm{H}_{2} \mathrm{SO}_{4}(\mathrm{~A})$ and $2 \%$ wt. $\mathrm{HCl}(\mathrm{B})$ on the amount of 5-HMF and furfural in hydrolysates

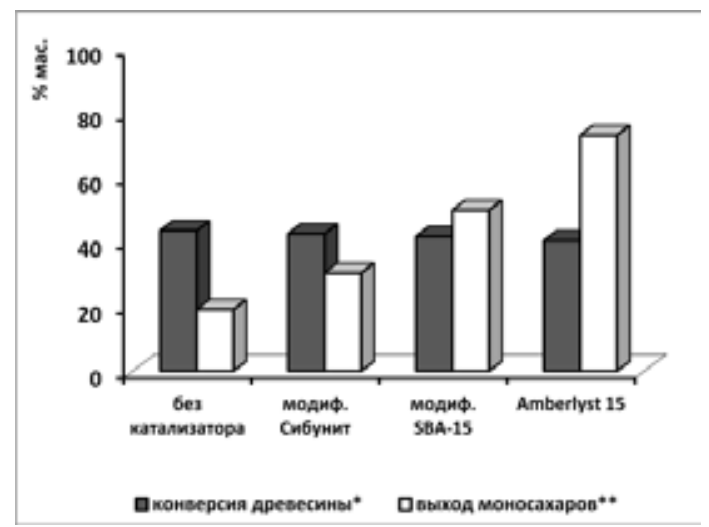

Рис. 3. Влияние природы твердых кислотных катализаторов на конверсию древесины осины в процессе гидролиза при температура $150{ }^{\circ} \mathrm{C}$ в течение 3 ч (*от массы абс. сух. древесины, ** от исходного содержания гемицеллюлоз в древесине)

Fig. 3. Effect of the nature of solid acid catalysts on the conversion of aspen wood in the hydrolysis at $150{ }^{\circ} \mathrm{C}$ during $3 \mathrm{~h}$ (* from the mass of abs. dry wood, ** from the initial content of hemicelluloses in wood)

катализатор $\mathrm{H}_{2} \mathrm{SO}_{4}$ ». Химический состав используемых лигноцеллюлозных продуктов из древесины осины приведен в табл. 2.

Из полученных данных следует, что выход лигноцеллюлозного продукта снижается в ряду катализаторов: $\mathrm{H}_{2} \mathrm{SO}_{4}\left(100^{\circ} \mathrm{C}\right)>\mathrm{HCl}\left(100^{\circ} \mathrm{C}\right)>\mathrm{SBA}-15\left(150^{\circ} \mathrm{C}\right) \sim$ Amberlyst-15 $\left(150{ }^{\circ} \mathrm{C}\right)$. В этой же последовательности катализаторов возрастает содержание целлюлозы в лигноцеллюлозном продукте от 66 до 73 \% мас. и снижается содержание гемицеллюлоз от 10,5 до 2,3 \% мас.

Пероксидная каталитическая делигнификация лигноцеллюлозных продуктов гидролиза древесины осуществлялась в мягких условиях (температура $100{ }^{\circ} \mathrm{C}$, атмосферное давление).

Влияние состава лигноцеллюлозных продуктов гидролиза древесины осины на выход и состав целлюлозных продуктов, полученных путем их пероксидной делигнификации, иллюстрируется данными, представленными в табл. 3. 
Таблица 2. Влияние условий гидролиза древесины осины на выход и состав лигноцеллюлозных продуктов

Table 2. Influence of conditions of aspen wood hydrolysis on the yield and composition of lignocellulosic products

\begin{tabular}{|c|l|c|c|c|c|}
\hline \multirow{2}{*}{$\begin{array}{c}\text { № } \\
\text { образца }\end{array}$} & Условия гидролиза & \multirow{2}{*}{$\begin{array}{c}\text { Выход лигноцеллю- } \\
\text { лозного } \\
\text { продукта, \% мас.* }\end{array}$} & \multicolumn{2}{|c|}{$\begin{array}{c}\text { Состав лигноцеллюлозного } \\
\text { продукта, \% мас** }\end{array}$} \\
\cline { 4 - 6 } & & целлюлоза & лигнин & $\begin{array}{c}\text { гемицеллю- } \\
\text { лозы }\end{array}$ \\
\hline 1 & $2 \%$ мас. $\mathrm{H}_{2} \mathrm{SO}_{4}, 100^{\circ} \mathrm{C}, 5$ ч & 72,0 & 66,0 & 23,4 & 10,5 \\
\hline 2 & $2 \%$ мас. $\mathrm{HCl}, 100^{\circ} \mathrm{C}, 4$ ч & 65,6 & 69,2 & 23,8 & 6,2 \\
\hline 3 & модиф. $\mathrm{SBA}-15,150{ }^{\circ} \mathrm{C}, 3$ ч & 58,9 & 72,5 & 25,2 & 2,5 \\
\hline 4 & Amberlyst $15,150{ }^{\circ} \mathrm{C}, 3$ ч & 59,7 & 73,0 & 24,7 & 2,3 \\
\hline
\end{tabular}

*- от массы абс. сух. древесины, ** - от массы абс. сух. лигноцеллюлозного продукта.

Таблица 3. Влияние состава лигноцеллюлозных продуктов из древесины осины на выход и состав целлюлозных продуктов, полученных путем их пероксидной делигнификации при $100{ }^{\circ} \mathrm{C}$ (условия делигнификации: 30 \% мас. $\mathrm{CH}_{3} \mathrm{COOH}, 5$ \% мас. $\mathrm{H}_{2} \mathrm{O}_{2}$, гидромодуль 15, продолжительность 3 ч, 2 \% мас. $\left.\mathrm{H}_{2} \mathrm{SO}_{4}\right)$

Table 3. Influence of the composition of lignocellulosic products from aspen wood on the yield and composition of cellulosic products obtained by their peroxide delignification at $100{ }^{\circ} \mathrm{C}$ (delignification conditions: $30 \% \mathrm{wt}$. $\mathrm{CH}_{3} \mathrm{COOH}, 5 \%$ wt. $\mathrm{H}_{2} \mathrm{O}_{2}$, hydro module 15 , time $3 \mathrm{~h}, 2 \%$ wt. $\mathrm{H}_{2} \mathrm{SO}_{4}$ )

\begin{tabular}{|c|c|c|c|c|c|}
\hline \multirow{2}{*}{$\begin{array}{c}\text { № } \\
\text { образца }\end{array}$} & \multirow{2}{*}{$\begin{array}{c}\text { Исходный } \\
\text { лигноцеллюлозный } \\
\text { продукт* }\end{array}$} & \multirow{2}{*}{$\begin{array}{c}\text { Выход целлюлозного } \\
\text { продукта, \% мас.** }\end{array}$} & \multicolumn{3}{|c|}{ Состав целлюлозного продукта, \% мас.*** } \\
\hline & & & целлюлоза & лигнин & $\begin{array}{c}\text { гемицел- } \\
\text { люлозы }\end{array}$ \\
\hline 1 & 1 & 47,5 & 94,8 & 0,1 & 5,3 \\
\hline 2 & 2 & 46,1 & 97,5 & 0,3 & 2,5 \\
\hline 3 & 3 & 37,6 & 98,5 & 0,5 & 0,3 \\
\hline 4 & 4 & 36,3 & 98,7 & 0,4 & 0,3 \\
\hline
\end{tabular}

* Состав приведен в табл. 2, **от массы абс. сух. древесины, *** от массы абс. сух. целлюлозного продукта.

Как и следовало ожидать, наиболее качественная целлюлоза образуется при пероксидной делигнификации лигноцеллюлозных продуктов 3 и 4, содержащих максимальное количество целлюлозы и минимальное количество гемицеллюлоз (табл. 2).

\section{Состав гидролизатов из целлюлозы осины}

Известно, что структура древесных целлюлоз сформирована из аморфной и кристаллической составляющих [31]. Повышение реакционной способности целлюлозы в процессах ее кислотного гидролиза достигается путем механической обработки в мельницах различной конструкции $[32,33]$. В процессе размола происходит уменьшение размера частиц и аморфизация кристаллической целлюлозы.

В настоящей работе для получения глюкозных гидролизатов использовали гидролиз 80 \% серной кислотой образцов мехактивированной целлюлозы, образующихся при пероксидной 
Таблица 4. Состав гидролизатов, полученных из древесины осины интеграцией каталитических процессов гидролиза гемицеллюлоз, пероксидной делигнификации лигноцеллюлозного продукта и гидролиза целлюлозы

Table 4. Composition of the hydrolysates obtained from aspen wood by integration of the catalytic processes of hemicelluloses hydrolysis, peroxide delignification of lignocellulosic product and cellulose hydrolysis

\begin{tabular}{|c|c|c|c|c|c|c|c|}
\hline \multirow[b]{2}{*}{$\begin{array}{l}\text { № } \\
\text { целлюлозного } \\
\text { продукта* }\end{array}$} & \multicolumn{5}{|c|}{ Состав гидролизатов, г/л** } & \multicolumn{2}{|c|}{$\begin{array}{l}\text { Теоретический выход } \\
\text { биоэтанола }\end{array}$} \\
\hline & 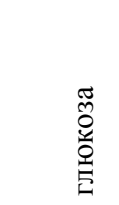 & 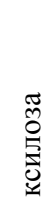 & 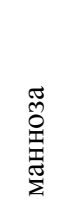 & $\sum_{\substack{1 \\
n}}^{\theta}$ & 竞 & 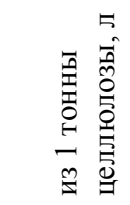 & 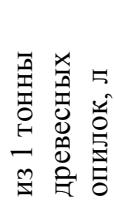 \\
\hline 1 & 88,7 & 5,7 & 1,5 & 0,09 & 0,14 & 581 & 276 \\
\hline 2 & 92,4 & 2,7 & 0,6 & 0,12 & 0,08 & 605 & 278 \\
\hline 3 & 97,0 & 0,4 & 0,3 & 0,18 & 0,02 & 636 & 239 \\
\hline 4 & 94,5 & 0,4 & 0,2 & 0,22 & 0,01 & 619 & 225 \\
\hline
\end{tabular}

* Состав приведен в табл. 3, ** получен гидролизом целлюлозы 80 \% $\mathrm{H}_{2} \mathrm{SO}_{4}$.

делигнификации лигноцеллюлозных продуктов гидролиза древесины осины. Ранее [27] нами были установлены оптимальные условия гидролиза микрокристаллической целлюлозы 80 \% $\mathrm{H}_{2} \mathrm{SO}_{4}$, обеспечивающие практически количественный выход глюкозы: температура $25{ }^{\circ} \mathrm{C}$, гидромодуль 1,4 , продолжительность гидролиза 47 мин и последующая инверсия гидролизата при $100^{\circ} \mathrm{C}$, гидромодуле 8 в течение 60 мин.

Состав гидролизатов и ожидаемый выход биоэтанола из образцов мехактивированной целлюлозы из древесины осины приведен в табл. 4.

Как следует из представленных в таблице 4 данных, максимальное содержание глюкозы в гидролизатах составляет 94,5-97,0 г/л, а минимальное содержание ксилозы 0,4 г/л и маннозы 0,2 г/л, что свидетельствует об эффективном удаление гемицеллюлоз на стадиях, предшествующих гидролизу древесной целлюлозы.

В случае применения растворенных катализаторов на стадии предварительного гидролиза гемицеллюлоз древесины при $100{ }^{\circ} \mathrm{C}$ выход биоэтанола, рассчитанный на 1 т древесины, выше на 40-50 л, чем при использовании твердых кислотных катализатров при $150{ }^{\circ} \mathrm{C}$ (табл. 4). Причиной этого является более высокий выход лигноцеллюлозных и целлюлозных продуктов, получаемых при температуре $100{ }^{\circ} \mathrm{C}$ (табл. 2 и 3).

Известно, что одним из наиболее токсичных компонентов гидролизатов, используемых для ферментативного синтеза биоэтанола, является фурфурол [34]. Установлено [35], что его допустимая концентрация в гидролизате, предназначенном для синтеза биоэтанола, не должна превышать 0,5 г/л. Допустимая концентрация 5-ГМФ в гидролизате составляет $<1,0$ г/л [36].

Методом ВЭЖХ установлено, что концентрация 5-ГМФ в полученных из древесины осины гидролизатах находится в пределах $0,1-0,22$ г/л. Наиболее высокую концентрацию фурфурола $(0,14$ г/л) содержит гидролизат, полученный из целлюлозного продукта с бо́льшим содержанием гемицеллюлоз (табл. 3). 
Таким образом, в полученных глюкозных гидролизатах из древесины осины, предназначенных для синтеза биоэтанола, концентрации 5-ГМФ и фурфурола существенно ниже допустимых значений.

\section{Заключение}

В результате выполненного исследования установлено, что качество получаемых из древесины осины глюкозных гидролизатов, а именно содержание глюкозы, ксилозы, примесей, ингибирующих ферментацию гидролизатов в биоэтанол, зависит от условий осуществления каталитических процессов кислотного гидролиза древесных полисахаридов в моносахара и пероксидной делигнификации древесины с получением целлюлозы.

Для гидролиза гемицеллюлоз древесины осины использованы растворенные кислотные катализаторы $2 \%$ мас. $\mathrm{H}_{2} \mathrm{SO}_{4}$ и $2 \%$ мас. $\mathrm{HCl}$ при температуре $100{ }^{\circ} \mathrm{C}$, а также твердые кислотные катализаторы Amberlyst-15, кислотно-модифицированные SBA-15 и Сибунит-4 при температуре $150{ }^{\circ} \mathrm{C}$. Максимальный выход моносахаров (преимущественно ксилозы) наблюдался при температуре гидролиза $100{ }^{\circ} \mathrm{C}$ в присутствии $\mathrm{HCl}$ (75 \% мас.) и при $150{ }^{\circ} \mathrm{C}$ в присутствии Amberlyst-15 (73,1 \% мас.). Выход лигноцеллюлозного продукта при гидролизе древесины осины снижается в ряду катализаторов: $\mathrm{H}_{2} \mathrm{SO}_{4}\left(100^{\circ} \mathrm{C}\right)>\mathrm{HCl}\left(100^{\circ} \mathrm{C}\right)>\mathrm{SBA}-15\left(150^{\circ} \mathrm{C}\right) \sim$ Amberlyst- $15\left(150^{\circ} \mathrm{C}\right)$. В этой же последовательности катализаторов возрастает содержание целлюлозы в лигноцеллюлозном продукте от 66 до 73 \% мас. и снижается содержание гемицеллюлоз от 10, 5 до 2,3\% мас.

Для получения качественной целлюлозы с чистотой до 98,7 \% мас. и содержанием остаточного лигнина и гемицеллюлоз менее 1 \% мас. предложено осуществлять пероксидную делигнификацию лигноцеллюлозных продуктов гидролиза древесины осины в среде уксусная кислота-вода при $100{ }^{\circ} \mathrm{C}$ в присутствии катализатора $2 \%$ мас. $\mathrm{H}_{2} \mathrm{SO}_{4}$.

Гидролиз целлюлозы из древесины осины $80 \%$ серной кислотой при температуре $25{ }^{\circ} \mathrm{C}$ позволяет получить глюкозные гидролизаты с выходом по глюкозе, близком к количественному. В полученных глюкозных гидролизатах из древесины осины, предназначенных для синтеза биоэтанола, концентрация ингибирующих примесей 5-ГМФ и фурфурола существенно ниже допустимых значений $(0,12-0,22$ г/л и $0,01-0,08$ г/л соответственно).

Исследование выполнено в рамках Комплексной программы фундаментальных исследований СО РАН № II.2 «Интеграция и развитие», проект № 0356-2015-0503.

\section{Список литературы}

1. Pulidindi I.N., Kimchi B.B., Gedanken A. Can cellulose be a sustainable feedstock for bioethanol production? Renew. Energy. 2014. Vol. 71, P. 77-80.

2. Rocha N., Barros M.A., Fischer J. at al. Ethanol production from agro industrial biomass using a crude enzyme complex produced by Aspergillus. Renew. Energy. 2013. Vol. 57, P. 432-435.

3. Singh A., Sharma P., Saran A.K. et al. Comparative study on ethanol production from pretreated sugarcane bagasse using immobilized Saccharomyces cerevisiae on various matrices. Renew. Energy. 2013. Vol. 50, P. 488-493.

4. Mousdale D.M. Introduction to biofuels. CRC: Press is an imprint of Taylor \& Francis Group, 2010. $421 \mathrm{p}$. 
5. Nelson V. Introduction to renewable energy. CRC: Press Taylor \& Francis Group, 2011. 350 p.

6. Saunders J.A., Rosentrater K.A. Survey of US fuel ethanol plants. Bioresource Technology. 2009. Vol. 100(13), P. 3277-3284.

7. Tan T., Shang F., Zhang X. Current development of biorefinery in China. Biotechnol. Adv. 2010. Vol. 28, P. 543-55.

8. Chen Y., Fu Y., Wang Zh., Qin M. Degradation and Redeposition of the Chemical Components of Aspen Wood during Hot Water Extraction. BioResources 2015. Vol. 10(2), P. 3005-3016.

9. Almeida, J.R.M., Modig, T., Petersson Anneli, Hähn-Hägerdal, B., Lidén, G., GorwaGrauslund M.F. Increased tolerance and conversion of inhibitors in lignocellulosic hydrolysates by Saccharomyces cerevisiae. Journal of Chemical Technology and Biotechnology. 2007. Vol. 82, P. 340349.

10. Jansson M., Berglin N., Olm L. Second generation ethanol through alkaline fractionation of pine and aspen wood. Cellulose Chem. Technol. 2010. Vol. 44 (1-3), P. 47-52.

11. Taherzadeh M.J., Karimi K. Acid-based hydrolysis processes for ethanol from lignocellulosic materials: A review. BioResources. 2007. Vol. 2(3), P. 472-499.

12. Westbye P., Köhnke T., Gatenholm P. Fractionation and characterization of xylan rich extracts from birch. Holzforschung. 2008. V. 62, P. 31-37.

13. Machado G., Leon S., Santos F., Lourega R., Dullius J., Mollmann M.E., Eichler P. Literature review on furfural production from lignocellulosic biomass. Natural Resources. 2016. Vol. 7, P. 115129.

14. Cotana F., Cavalaglio G., Nicolini A., Gelosia M., Coccia V., Petrozzi A., Brinchi L. Lignin as co-product of second generation bioethanol production from lingo-cellulosic biomass. Energy Procedia. 2014. Vol. 45, P. 52-60.

15. Chemin M., Wirotius A-L., Ham-Pichavant F. Well-defined oligosaccharides by mild acidic hydrolysis of hemicelluloses. European Polymer Journal. 2015. V. 66, P. 190-197.

16. Takagaki A., Nishimura M., Nishimura S. Hydrolysis of sugars using magnetic silica nanoparticles with sulfonic acid groups. Chem. Lett. 2011. Vol. 40, P. 1195-1197.

17. Vilcocq L., Castilho P.C., Carvalheiro F., Duarte L.C. Hydrolysis of oligosaccharides over solid acid catalysts: a review. Chem Sus Chem. 2014. Vol. 7, P. 1010-1019.

18. Kuznetsov B.N., Sudakova I.G., Garyntseva N.V., Djakovitch L., Pinel C. Kinetic studies and optimization of abies wood fractionation by hydrogen peroxide at mild conditions with $\mathrm{TiO}_{2}$ catalyst. Reaction Kinetics, Mechanism and Catalysis. 2017. Vol. 120(1), P. 81-94.

19. Tarabanko V.E., Kaygorodov K.L., Skiba E.A., Tarabanko N.V., Chelbina Yu.V., Baybakova O.V., Kuznetsov B.N., Djakovitch L. Processing pine wood into vanillin and glucose by sequential catalytic oxidation and enzymatic hydrolysis. J. of Wood Chemistry and Technology. 2017. Vol. 37(1), P. 43-51.

20. Kuznetsov B.N., Chesnokov N.V., Yatsenkova O.V., Sharypov V.I., Garyntseva N.V., Ivanchenko N.M., Yakovlev V.A. Green catalytic valorization of hardwood biomass into valuable chemicals with the use of solid catalysts. Wood Science and Technology. 2017. Vol. 51(5), P. 11891208.

21. Tappi, 2009. Carbohydrate composition of extractive-free wood and wood pulp by gas-liquid chromatography (Reaffirmation of T $249 \mathrm{~cm}-09$ ).

22. Tappi, 2006. Acid-insoluble lignin in wood and pulp (Reaffirmation of T $222 \mathrm{om}-02$ ).

$$
-343-
$$


23. Sluiter J.B., Ruiz R.O., Scarlata CH.J., Sluiter A.D., Templeton D.W. Compositional analysis of lignocellulosic feedstocks. 1. Review and description of methods. J. Agric. Food Chem. 2010. V. 58, P. 9043-9053.

24. Tappi, 2002. Ash in wood, pulp, paper and paperboard: combustion at $525^{\circ} \mathrm{C}$ (Reaffirmation of T 211 om-02).

25. Pang J., Wang A., Zheng M., Zhang T. Hydrolysis of cellulose into glucose over carbons sulfonated at elevated temperatures. Chem. Commun. 2010. Vol. 46, P. 6935-6937.

26. Яценкова О.В., Судакова И.Г., Скрипников А.М., Кузнецов Б.Н. Влияние условий пероксидной каталитической делигнификации древесины березы на выход и состав целлюлозных продуктов. Ж. Сибирского федерального университета. 2016. Т. 9(2), С. 188-200. [Yatsenkova O.V., Sudakova I.G., Skripnikov A.M., Kuznetsov B.N. The Influence of Conditions of Birch Wood Peroxide Catalytic Delignification on the Yield and Composition of Cellulosic Products. Journal of Siberian Federal University. Chemistry. 2016. Vol. 9(2), P. 188-200. (In Russ.)]

27. Яценкова О.В., Пен Р.З., Скрипников А.М., Береговцова Н.Г., Кузнецов Б.Н. Оптимизация процесса гидролиза микрокристаллической целлюлозы концентрированной серной кислотой. Химия в интересах устойчивого развития. 2016. Т. 24(6), С. 811-819 [Yatsenkova O.V., Pen. R.Z., Skripnikov A.M., Beregovtsova N.G., Kuznetsov B.N. Optimization of the Hydrolysis Process of Microcrystalline Cellulose with Concentrated Sulphuric Acid. Chemistry for Sustainable Development. 2016. Vol. 24(6), P. 811-819. (In Russ.)]

28. Ruiz-Matute A.I., Hernandez-Hernandez O., Rodriguez-Sanchez S., Sanz M.L., MartinezCastro I. J. Chromatogr. B. 2011. Vol. 879, P. 1226-1240.

29. Hu G., Heitmann J.A., Rojas O. Feedstock pretreatment strategies for producing ethanol from wood, bark and forest residues. BioResources. 2008. Vol. 3(1), P. 270-294.

30. Klinke H.B., Thomsen A.B., Ahring B.K. Inhibition of ethanol-producing yeast and bacteria by degradation products produced during pre-treatment of biomass. Mini-review. Appl. Microbiol. Biotechnol. 2004. Vol. 66, P. 10-26.

31. Siró I., Plackett D. Microfibrillated cellulose and new nanocomposite materials: a review. Cellulose. 2010. 17(3), P. 459-494.

32. Кузнецов Б.Н., Яценкова О.В., Чудина А.И., Скрипников А.М., Козлова С.А., Гарынцева Н.В., Чесноков Н.В. Влияние механической и химической активации микрокристаллической целлюлозы на ее строение и реакционную способность в гидролизе с твердым кислотным катализатором SBA-15. Журнал Сибирского федерального университета. Химия. 2014. Т. 7(1), С. 122 133. [Kuznetsov B.N., Yatsenkova O.V., Chudina A.I., Skripnokov A.M., Kozlova S.A., Garyntseva N.V., Chesnokov N.V. Influence of Mechanical and Chemical Activation of Microcrystalline Cellulose on its Structure and Reaction Ability in Hydrolysis Over Solid Acid Catalyst SBA-15. Journal of Siberian Federal University. Chemistry. 2016. Vol. 7(1), P. 122-133. (In Russ.)]

33. Пестунов А.В., Кузьмин А.О., Яценко Д.А., Правдина М.Х., Таран О.П. Механическая активация чистой и содержащейся в древесных опилках целлюлозы в мельницах различного типа. Журнал Сибирского федерального университета. Химия. 2015. Т. 8(3), С. 386-400. [Pestunov A.V., Kuzmin A.O., Yatsenko D.A., Pravdina M.Kh., Taran O.P. The Mechanical Activation of Crystal and Wooden Sawdust Cellulose in Various Fine-Grinding Mills. Journal of Siberian Federal University. Chemistry. 2015. Vol. 8(3), P. 386-400. (In Russ.)] 
34. Mills T.Y., Sandoval N.R., Gill R.T. Cellulosic hydrolysate toxicity and tolerance mechanisms in Escherichia coli. Biotechnology for Biofuels. 2009. Vol. 2, P. 26-36.

35. Huang H., Guo X., Li D., Liu M., Wu J., Ren H. Identification of crucial yeast inhibitors in bio-ethanol and improvement of fermentation at high $\mathrm{pH}$ and high total solids. Bioresource Technology. 2011. Vol. 102, P. 7486-7493.

36. Zha Y., Westerhuis J.A., Muilwijk B., Overkamp K.M., Nijmeijer B.M., Coulier L., Smilde A.K., Punt P.J. Identifying inhibitory compounds in lignocellulosic biomass hydrolysates using an exometabolomics approach. BMC Biotechnology. 2014. Vol. 14, P. 22-38. 